\title{
Biotech on the Rise: The Treatment of Psoriasis with Biological Drugs
}

\author{
Daria Capece et al.* \\ Department of Experimental Medicine, \\ University of L'Aquila, L'Aquila \\ Italy
}

\section{Introduction}

Psoriasis is a chronic inflammatory skin disorder affecting $1-3 \%$ of the general population worldwide. Up to one-third of psoriatic patients have concomitant psoriatic arthritis (Gerdes et al, 2009). Multiple studies and clinical trials support an important role for dysregulation of the immune system in the development of psoriasis. In recent years, the improved understanding of the molecular basis underlying psoriasis has led to the introduction of biological drugs, providing a new effective treatment option for this disease. Biologics target key steps in the pathogenesis of psoriasis, and can be classified into three main categories: TNF $\alpha$ inhibitors, T cell inhibitors and IL-12/IL-23 inhibitors (Weger, 2010). In this chapter we discuss the state of the art of biological therapies for psoriasis and psoriatic arthritis and give a brief overview of the new biological approaches that are currently undergoing evaluation for the treatment of both diseases.

\section{TNF $\alpha$ Inhibitors}

$\mathrm{TNF} \alpha$ is a proinflammatory cytokine that plays key roles in both innate and adaptive immunity. At high concentrations, it can trigger an excessive inflammatory response ending in organ damage. The development of anti-TNF $\alpha$ biologics originated from a study by Brennan et al., which showed that the expression of pro-inflammatory cytokines by synoviocytes in rheumatoid arthritis patients was inhibited by TNF-neutralizing antibodies (Brennan et al, 1989). To date, the role of TNF $\alpha$ in psoriasis and psoriatic arthritis has been fully investigated (Schottelius et al, 2004). Increased levels of TNF $\alpha$ and a differential expression of TNF $\alpha$ receptors I and II have been found in lesional psoriatic skin compared with normal-appearing skin; in addition, in psoriatic patients, the plasma concentration of $\mathrm{TNF} \alpha$ is higher and the mRNA expression of this cytokine is increased in peripheral blood

\footnotetext{
*Valeria Iansante1, Mariafausta Fischietti ${ }^{1}$, Daniela Verzella1, Maria Concetta Fargnoli², Ketty Peris², Roberto Giacomelli ${ }^{3}$, Francesca Zazzeroni ${ }^{1}$ and Edoardo Alesse ${ }^{1}$

${ }^{1}$ Department of Experimental Medicine, University of L'Aquila, L'Aquila, Italy

${ }^{2}$ Department of Sciences and Biomedical Technology, University of L'Aquila, L'Aquila, Italy

${ }^{3}$ Department of Internal Medicine and Public Health, University of L'Aquila, L'Aquila, Italy
} 
mononuclear cells. Currently, four TNF $\alpha$ antagonists are approved for the treatment of psoriasis and/or psoriatic arthritis, namely etanercept, infliximab, adalimumab and golimumab; a new TNF $\alpha$ inhibitor (certolizumab pegol) is currently undergoing a phase III trial for the treatment of psoriatic arthritis.

\subsection{Etanercept}

Etanercept is a recombinant human fusion protein consisting of a dimer of the extracellular portion of TNF $\alpha$ receptor II linked to the Fc portion of IgG1 (Amgen, Inc, 2011). Etanercept binds to both the trimeric form of soluble $\mathrm{TNF} \alpha$ and to the transmembrane form, antagonizing their biological actions (Bachmann et al, 2010). Several studies reported a reduction of different inflammatory cell types in psoriatic lesions during etanercept treatment, such as T cells, natural killer cells, neutrophils, macrophages and plasmocytoid dendritic cells (de Groot et al, 2010). Etanercept also blocks downstream T-cell mediated events inducing apoptosis of CD11c+ myeloid dendritic cells (Malaviya et al, 2006). In addition, etanercept has been shown to down-regulate Th17 cell markers, as well as Th17 cell products and effector molecules (Antiga et al, 2010; Zaba et al, 2007). Etanercept is FDAand EMA-approved for the treatment of psoriasis and psoriatic arthritis. It is also approved for the treatment of other autoimmune conditions such as rheumatoid arthritis, juvenile idiopathic arthritis and ankilosing spondilytis (Amgen, Inc., 2011).

\subsubsection{Administration}

Etanercept is administered subcutaneously at a dose of $50 \mathrm{mg}$ twice a week in patients with plaque psoriasis or at $25 \mathrm{mg}$ twice a week in patients with psoriatic arthritis during the first 12 weeks of treatment. After the initiation phase, the dosage for plaque psoriasis is reduced to $25 \mathrm{mg}$ twice a week or $50 \mathrm{mg}$ weekly during the maintenance phase (Amgen, Inc., 2011). Etanercept can be administered either continuously or intermittently. Gordon et al reported no loss of efficacy with intermittent therapy, with a similar response between retreatment and initial therapy in psoriatic patients (Gordon et al, 2006a). However, a multicenter European open-label study showed that both regimens provide a significant improvement in quality of life, with a greater improvement in the continuous treatment group (Dauden et al, 2009). Non-neutralizing anti-etanercept antibodies have been observed by several authors, but the relevance of them is still debated (Bachmann et al, 2010).

\subsubsection{Clinical efficacy}

Several high-quality clinical trials (Cassano et al, 2010; Gottlieb et al, 2003; Leonardi et al, 2003, 2010; Papp et al, 2005; Tyring et al, 2007; van de Kerkhof et al, 2008) have evaluated both the short-term and long-term efficacy of etanercept in the treatment of psoriasis. In clinical trials, the severity of psoriasis is assessed by the Psoriasis Area and Severity Index (PASI). PASI 75 is defined as a 75\% reduction in PASI score compared with baseline. An initial randomized, double-blind, placebo-controlled, multicenter trial of 112 patients demonstrated a PASI 75 response in $30 \%$ of patients receiving $25 \mathrm{mg}$ etanercept twice a week compared with $2 \%$ of placebo-treated patients after 12 weeks. After 24 weeks, PASI 75 response increased to $56 \%$ in the etanercept-treated arm compared with $5 \%$ in the placebo group (Gottlieb et al, 2003). Leonardi et al. demonstrated that the efficacy of etanercept is 
dose-related, reporting a PASI 75 response in $34 \%$ and $49 \%$ of patients treated with $25 \mathrm{mg}$ and $50 \mathrm{mg}$ twice weekly after 12 weeks of treatment, respectively. The improvement continued through week 24 , with $44 \%$ and $59 \%$ of patients achieving a PASI 75 , respectively (Leonardi et al, 2003). The same high-dose etanercept regimen was used in a recent study by Griffiths et al., who reported a PASI 75 response in $57 \%$ of patients after 12 weeks of treatment (Griffiths et al, 2010). In a further multicentre 24-week study, the efficacy of etanercept during the initial treatment phase and after dose reduction were evaluated (Papp et al, 2005). Patients were treated with a dose of $50 \mathrm{mg}$ etanercept, $25 \mathrm{mg}$ etanercept or placebo twice weekly for the first 12 weeks. During the second 12 weeks of treatment, the dosage was reduced to $25 \mathrm{mg}$ twice weekly. Papp et al. reported a PASI 75 in $49 \%$ of patients treated with $50 \mathrm{mg}$ twice weekly and in $34 \%$ of patients receiving $25 \mathrm{mg}$ twice weekly of etanercept compared with $3 \%$ in the placebo group at week 12, and demonstrated that the effect obtained with the higher dose could be preserved in most patients after dose reduction (Papp et al, 2005). A further increase of the dose of etanercept to $100 \mathrm{mg}$ did not demonstrate an improvement in efficacy (Cassano et al, 2006). Recent data by van de Kerkhof et al. demonstrated that etanercept $50 \mathrm{mg}$ once weekly for 24 weeks was effective, with a PASI 75 response of $38 \%$ after 12 weeks, which increased to $71 \%$ after 24 weeks (van de Kerkhof et al, 2008). Similar results were reported by Sterry et al. (Sterry et al, 2010). Regarding long-term efficacy, etanercept response has been demonstrated to last up to 96 weeks, resulting in a statistically significant improvement (Tyring et al, 2007; Esposito et al, 2010). Etanercept is the only biological drug that has shown efficacy and safety in pediatric patients with moderate to severe plaque psoriasis (Paller et al, 2008). Paller et al. reported a PASI 75 response in $57 \%$ of children and adolescents treated with etanercept $(0.8 \mathrm{mg} / \mathrm{kg}$ body weight $)$ compared with $11 \%$ in placebo patients after 12 weeks. The efficacy of the treatment was maintained through 96 weeks (Paller et al, 2010). Treatment with etanercept also provides an improvement in the quality of life of patients, as measured by the Dermatology Life Quality Index (DLQI) (Leonardi et al, 2003; van de Kerkhof et al, 2008).

Two pivotal studies have demonstrated the efficacy of etanercept in the treatment of psoriatic arthritis. In these studies, the American College of Rheumatology (ACR) criteria is the most frequently parameter used to assess the severity of psoriatic arthritis. A doubleblind, placebo-controlled study enrolling 60 patients suffering from psoriatic arthritis showed achievement of ACR 20, ACR 50 and ACR 70 response in $73 \%, 50 \%$ and $13 \%$ of patients after 12 weeks of treatment with etanercept, compared with $13 \%, 3 \%$ and $0 \%$ in the placebo group (Mease et al, 2000). Furthermore, the same authors reported an additional double-blind, placebo-controlled clinical trial in 250 patients with psoriatic arthritis. At 12 weeks, an ACR 20 response was observed in 59\% of etanercept-treated patients compared with $15 \%$ of the placebo group. This study also reported an improvement in quality of life measured by the Health Assessment Questionaire (HAQ) (Mease et al, 2004). The improvements observed were maintained for up to 2 years (Mease et al, 2010). A recent study by Saougou et al. reported a PASI 90 response in $68 \%$ of etanercept-treated patients affected by psoriatic arthritis after 5 years (Saougou et al, 2011).

Although highly effective as monotherapy, few studies have been published on the combination of etanercept with cyclosporine, narrowband UVB, acitretin and methotrexate (reviewed in Foley et al, 2010). Preliminary data from short-term analysis support the use of etanercept in combination therapy which does not seem to be associated with additional 
toxicities. This provides an attractive option for patients inadequately responding to monotherapy. However, further long-term studies are needed to confirm the safety of combination therapy.

\subsection{Infliximab}

Infliximab is a chimeric IgG anti-TNF $\alpha$ monoclonal antibody constiting of a human constant $(75 \%)$ region and murine variable $(25 \%)$ regions (Centocor Ortho Biotech, Inc., 2011). In vivo, infliximab binds to human TNF $\alpha$ and forms stable complexes, resulting in the loss of biological activity of this pro-inflammatory cytokine (Scallon et al, 1995). Infliximab is able to neutralize both soluble and trans-membrane TNF $\alpha$ and induces the elimination of TNF $\alpha$ bearing cells, such as macrophages, dermal dendritic cells, and T cells (Gisondi et al, 2004; Zaba et al, 2007). Recently, it has been suggested that infliximab induces p53-related keratinocytes apoptosis, highlighting another effect of this drug in psoriasis (Raho et al, 2011). Infliximab is FDA- and EMA-approved for the treatment of psoriasis, psoriatic arthritis, rheumatoid arthritis, ankylosing spondylitis, adult and pediatric Crohn's disease and ulcerative colitis (Centocor Ortho Biotech, Inc., 2011).

\subsubsection{Administration}

Infliximab is administered as a 2-3 hour intravenous infusion at a dose of $5 \mathrm{mg} / \mathrm{kg}$. The infusions are given at weeks 0,2 and 6 (induction period) and then every 8 weeks (maintenance period) (Centocor Ortho Biotech, Inc., 2011). The efficacy of continuous versus intermittent treatment was evaluated in the clinical trial EXPRESS II, reporting that continuous treatment achieved better results than intermittent therapy to maintain PASI response and to reduce the occurrence of anti-infliximab antibodies, the most common cause of decreased drug efficacy (Haraoui et al, 2006; Menter et al, 2007; Vena \& Cassano, 2007).

\subsubsection{Clinical efficacy}

Several pivotal clinical trials demonstrated the clinical efficacy of infliximab in the treatment of plaque psoriasis (Chaudhari et al, 2001; Gottlieb et al, 2004; Reich et al, 2005, 2006). Two phase II studies evaluated the efficacy of infliximab at different doses, 5 and $10 \mathrm{mg} / \mathrm{kg}$ and 3 and $5 \mathrm{mg} / \mathrm{kg}$, respectively (Chaudhari et al, 2001; Gottlieb et al, 2004). In the first study of 33 psoriatic patients, a PASI 75 response was observed in $82 \%$ and $73 \%$ of patients receiving 5 and $10 \mathrm{mg} / \mathrm{kg}$ of infliximab, respectively, and in $8 \%$ of the patients receiving placebo after 10 weeks. In the second study (SPIRIT) of 249 plaque psoriasis patients, $72 \%$ and $88 \%$ of patients receiving 3 and $5 \mathrm{mg} / \mathrm{kg}$ of infliximab, respectively, achieved PASI 75 at week 10 compared with $6 \%$ of the placebo-treated patients. These results demonstrated a high shortterm efficacy of infliximab and identified $5 \mathrm{mg} / \mathrm{kg}$ as the ideal dosage regimen in the treatment of psoriasis. The rapid response induced by infliximab decreased after 50 weeks (Reich et al, 2005). The phase III multi-center, double-blind, placebo-controlled trial EXPRESS enrolled 378 patients with plaque psoriasis and showed a PASI 75 response in $80 \%$ of the patients after 10 weeks compared with $3 \%$ in placebo group. The response was maintained through week 24 and decreased to $61 \%$ by week 50 . Nevertheless, the retrospective analysis of the EXPRESS trial showed that infliximab continuous therapy for 1 
year resulted in a sustained improvement in PASI score (Reich et al, 2010). Moreover, infliximab provides a substantial improvement in quality of life, with a meaningful decrease in DLQI both in short-term and long-term treatment (Feldmann et al, 2005; Gottlieb et al, 2004; Menter et al, 2007; Reich et al, 2006, 2010).

The IMPACT trial evaluated the efficacy of infliximab in 104 patients with psoriatic arthritis (Antoni et al, 2005a). At week 16, 65\% of patients achieved ACR 20 compared with 10\% of the placebo group and $46 \%$ and $29 \%$ achieved ACR 50 and ACR 70, respectively. The efficacy of infliximab has been evaluated in a larger cohort of patients $(n=200)$ in the IMPACT 2 trial. At week 14, 64\% of infliximab-treated patients showed a PASI 75 response and 58\% achieved ACR 20; in addition ACR 20 criteria were maintained up to 1 year (Antoni et al, 2005b; Kavanaugh et al, 2007). The long-term efficacy of infliximab was evaluated by a two-year extension of the IMPACT trial (Antoni et al, 2008). At week 98, maintenance of the ACR 20 criteria was observed in $68 \%$ of infliximab-treated patients and $64 \%$ of them achieved PASI 75.

Regarding combination therapy, the concomitant administration of methotrexate has been reported to prolong the long-term efficacy of infliximab by decreasing the development of human anti-infliximab neutralizing antibodies (Klotz et al, 2007).

\subsection{Adalimumab}

Adalimumab is the first fully humanized recombinant anti-TNF $\alpha$ monoclonal antibody. Adalimumab is able to bind both soluble and membrane-bound TNF $\alpha$ in a dose-dependent manner (Abbott Laboratories, 2011). It has been shown that adalimumab lyses TNF $\alpha-$ bearing cells in the presence of complement and induces apoptosis in vitro; in addition adalimumab affects the biological responses controlled by TNF $\alpha$, such as the expression of adhesion molecules, serum concentration of cytokines, reactive oxygen species and dendritic cells in psoriatic plaques (Papoutsaki et al, 2007). Moreover, adalimumab is able to modulate Toll-like receptors expression on basal keratinocytes (De Pità et al, 2011). Adalimumab is FDA- and EMA-approved for the treatment of psoriasis, psoriatic arthritis, rheumatoid arthritis, Crohn's disease, juvenile idiopathic arthritis and ankylosing spondylitis (Abbott Laboratories, 2011).

\subsubsection{Administration}

Adalimumab is administered as a subcutaneous injection and the recommended dose for psoriasis is a loading dose of $80 \mathrm{mg}$ at week one, followed by $40 \mathrm{mg}$ at week two and continuous $40 \mathrm{mg}$ injection every other week (eow) for maintenance. In psoriatic arthritis the ideal dosage regimen is $40 \mathrm{mg}$ every second week (Abbott Laboratories, 2011). The continuous therapy with adalimumab seems to be more effective than intermitted therapy to provide a sustained response (Menter et al, 2008). Recently, encouraging results have been obtained in the retreatment of patients who relapsed after interruption of adalimumab therapy (Papp et al, 2011) and patients who lost efficacy during treatment with another TNF $\alpha$ antagonist (Van et al, 2008). Development of anti-adalimumab antibodies may occur, as demonstrated in patients with rheumatoid arthritis (Bartelds et al, 2010). 


\subsubsection{Clinical efficacy}

The clinical efficacy of adalimumab was analyzed by three main clinical trials (Gordon et al, 2006b; Menter et al, 2008; Saurat et al, 2008). In an earlier phase II study enrolling 147 psoriatic patients, two dose regimens of adalimumab were evaluated. Gordon et al. reported a PASI 75 improvement in $80 \%$ of patients treated with $40 \mathrm{mg}$ weekly and in $53 \%$ of patients receiving $40 \mathrm{mg}$ eow compared with $4 \%$ of patients in the placebo group at week 12 . At week 60, PASI 75 response was observed in $64 \%$ and $56 \%$ of patients treated with $40 \mathrm{mg}$ weekly or $40 \mathrm{mg}$ eow, respectively (Gordon et al, 2006b). The phase III placebo-controlled randomized trial by Menter et al. of 1212 patients with plaque psoriasis evaluated the efficacy of adalimumab $40 \mathrm{mg}$ eow. The authors reported a PASI 75 response rate in $71 \%$ of the patients after 16 weeks and in $70 \%$ after 24 weeks of $40 \mathrm{mg}$ eow adalimumab therapy; the efficacy decreased during weeks 33 to 52 (Menter et al, 2008). The first head-to-head trial CHAMPION compared adalimumab vs methotrexate and reported a PASI 75 response in $80 \%$ of patients in the adalimumab $40 \mathrm{mg}$ eow group, in $36 \%$ of patients in the methotrexate group and in 19\% of those in the placebo group (Saurat et al, 2008). An improvement in DLQI after treatment with adalimumab has been reported by several studies (Menter et al, 2010; Revicki et al, 2008; Saurat et al, 2008; Shikiar et al, 2007).

The clinical efficacy of adalimumab in psoriatic arthritis has also been described (Genovese et al, 2007; Gladman et al, 2007; Mease et al, 2005, 2009). The ADEPT trial involving 315 psoriatic arthritis patients tested the long-term clinical efficacy of adalimumab through 2 years. Mease et al. reported that $58 \%$ of patients treated with adalimumab achieved the ACR 20 after 12 weeks compared with $14 \%$ of the patients in the placebo group and that similar percentages were maintained up to week 104 (Mease et al, 2005, 2009). These data were confirmed by Genovese et al. who reported an ACR 20 response in $65 \%$ of adalimumabtreated patients after week 24 (Genovese et al, 2007).

Recently, the use of adalimumab in combination with traditional therapies was evaluated in psoriasis. Adalimumab with methotrexate results in a lower discontinuation rate of the TNF $\alpha$ antagonist (Heiberg et al, 2008); the concomitant administration of adalimumab with phototherapy seems to be clinically effective, but further investigations in controlled clinical trials are needed (Bagel, 2011). The use of topical agents in combination with adalimumab results in a higher short-term efficacy that decreases after 4 weeks (Thaçi et al, 2010).

\subsection{Golimumab}

Golimumab is a new TNF $\alpha$ antagonist and, like adalimumab, is a fully human anti-TNF $\alpha$ IgG monoclonal antibody, which binds to both soluble and transmembrane forms of TNF $\alpha$. Golimumab has been recently FDA- and EMA-approved for the treatment of psoriatic arthritis as monotherapy or in combination with methotrexate. Golimumab is also approved for controlling symptoms of rheumatoid arthritis and ankylosing spondylitis (Centocor Ortho Biotech, Inc., 2010).

\subsubsection{Administration}

Golimumab is the first patient-administered once-monthly anti-TNF $\alpha$ drug. The recommended dosage is $50 \mathrm{mg}$ subcutaneously every 4 weeks (Centocor Ortho Biotech, Inc., 2010). 


\subsubsection{Clinical efficacy}

The phase III GO-REVEAL clinical trial evaluated the efficacy of golimumab in 405 patients suffering from active psoriatic arthritis (Kavanaugh et al, 2009a). Patients received $50 \mathrm{mg}$, $100 \mathrm{mg}$ or placebo once every 4 weeks. Achievement of ACR 20 criteria at week 14 was the primary end-point and was observed in $51 \%$ of patients treated with $50 \mathrm{mg}$, in $45 \%$ of patients receiving $100 \mathrm{mg}$ of golimumab and in $9 \%$ of patients in the placebo group. At 24 weeks, Kavanaugh et al. reported further improvement, with $52 \%$ and $61 \%$ of patients treated with $50 \mathrm{mg}$ and $100 \mathrm{mg}$ achieving ACR 20 criteria, respectively, compared with only $12 \%$ of patients in the placebo group. At week 14 , a PASI 75 was achieved in $40 \%$ and in $58 \%$ of patients receiving $50 \mathrm{mg}$ and $100 \mathrm{mg}$ golimumab, respectively, compared to $3 \%$ of patients receiving placebo (Kavanaugh et al, 2009a). Long-term efficacy of golimumab was evaluated in a 2-year trial (Kavanaugh et al, 2009b). At week 52, the percentage of patients treated with $50 \mathrm{mg}$ of golimumab achieving ACR 20 and PASI 75 responses was $78 \%$ and $62 \%$, respectively. At week 104, the proportion of patients with the aforementioned clinical responses increased to $91 \%$ and $69 \%$, respectively. With regard to the group of patients who received $100 \mathrm{mg}$ of golimumab, Kavanaugh et al. observed an ACR 20 response in $81 \%$ and in $73 \%$ of patients at week 52 and 104, respectively. At the same time points, the percentage of patients achieving a PASI 75 was $70 \%$ and $76 \%$, respectively (Kavanaugh et al, 2009b). The authors also reported an improvement in physical function and quality of life (Kavanaugh et al, 2009a).

\subsection{Certolizumab pegol}

Certolizumab Pegol is another TNF $\alpha$ antagonist approved for the treatment of rheumatoid arthritis and Crohn's disease (UCB, Inc., 2010). It is a pegylated Fab fragment of a humanized anti-TNF $\alpha$ antibody. The presence of polyethylene glycol prolongs serum halflife of the drug. Certolizumab pegol is unable to induce antibody-dependent cell-mediated cytotoxicity and complement-dependent cytotoxicity because of the lack of the Fc region (Bourne et al, 2008). Preliminary data from two phase II clinical trials showed that certolizumab pegol is effective in patients with moderate to severe plaque psoriasis (Ortonne et al, 2007, 2008a, 2008b). In these studies the efficacy and safety at two different dose regimens were evaluated. Patients were treated with $200 \mathrm{mg}, 400 \mathrm{mg}$ of certolizumab pegol or placebo every two weeks subcutaneously. At week 12, a PASI 75 response was observed in $74.6 \%$ of patients receiving $200 \mathrm{mg}$ and in $82.8 \%$ of $400 \mathrm{mg}$ treated-patients compared with $6.8 \%$ of patients in the placebo group (Ortonne et al, 2007). The same authors showed that at week 12 a higher number of patients achieved PASI 90 and had a greater improvement in health-related quality of life (Ortonne et al, 2008a, 2008b). A phase III trial of certolizumab pegol for psoriatic arthritis is ongoing (UCB, Inc., 2010).

\subsection{Safety of TNF inhibitors}

The aforementioned clinical trials show that TNF $\alpha$ antagonists are well tolerated and safe. The commonest side effect associated with etanercept, adalimumab and golimumab treatment is a reaction at the site of injection, including redness, itching, bruising, pain, swelling and/or irritation as well as allergic reactions such as latex allergy (Kerbleski \& Gottlieb, 2011). Treatment with infliximab is associated with infusion reactions, occurring in around $20 \%$ of patients, including pruritus, headache, rash, urticaria, fever or anaphylactic 
reactions (Leman \& Burden, 2008). For all TNFa inhibitors, the primary concern is the increased risk for viral, bacterial and fungal infections, mainly of the upper respiratory tract (Kunz, 2009). Therapy with anti-TNF agents can lead to reactivation of latent tuberculosis, more frequently with infliximab (associated with the highest risk) and adalimumab than etanercept (Dixon et al, 2006). Another safety issue is the development of malignancies. The use of TNF $\alpha$ inhibitors is associated with an increased risk of non-melanoma skin cancer (NMSC); the occurence of NMSC may be due to the previous use of phototeraphy and immunosuppressive agents, even if a potential risk to develop cancer after antiTNF $\alpha$ therapy cannot be excluded (Kerbleski \& Gottlieb, 2011). A paradoxical side effect of anti-TNF therapies is the new onset and worsening of psoriasis, which have been reported in some cases (Ko et al, 2009). Infliximab, adalimumab and golimumab have been shown to cause hepatotoxicity (Kavanaugh et al, 2009a; Reich et al, 2005). On the contrary, etanercept seems to be effective and safe in the treatment of psoriatic patients with chronic hepatitis $C$ virus-infection (Piccolo et al, 2008; Zeinn et al, 2005). Moreover, TNF inhibitors can potentially worsen congestive heart failure (Chung et al, 2009). The TNF blockade can lead to development of antinuclear antibodies and anti-double-stranded DNA antibodies. A lupus-like syndrome may occur with TNF antagonists, but it is a rare event that reverts after discontinuation of therapy (Ramos-Casals et al, 2008). Other rare events associated with TNF antagonists are the development of serious hematological diseases, such as leukopenia, neutropenia, thrombocytopenia, pancytopenia or aplastic anemia and the development or worsening of peripheral and central demyelinating disorders (Montane et al, 2007; Roberts \& McColl, 2004). Rare dermatological diseases such as erythema multiforme, Steven's Johnson syndrome and toxic epidermal necrolysis have been reported during etanercept, infliximab and adalimumab treatment (Kerbleski \& Gottlieb, 2011).

\section{T-cell inhibitors}

Psoriasis is defined as a $\mathrm{T}$ cell-mediated autoimmune disease based on the advanced understanding of its pathogenesis. Primarily, a deregulated Th1/Th17 response has been reported in psoriatic skin (Lowes et al, 2008). Due to the primary role that $\mathrm{T}$ cells play in this disease, a new class of biologics has been designed to interfere with T-cell activation and functions. Currently, alefacept is the only T cell inhibitor drug approved for the treatment of psoriasis. Efalizumab was withdrawn from the market because of the associated risk of progressive multifocal leukoencephalopathy. Two other T-cell modulators are currently being evaluated for their use in psoriasis and psoriatic arthritis.

\subsection{Alefacept}

Alefacept is a recombinant human fusion protein consisting of the soluble lymphocyte function-associated antigen-3 (LFA-3) and the IgG1 Fc fragment (Biogen Inc., 2003). The LFA-3 portion binds to CD2, highly expressed on CD4+ and CD8+ memory-effector T cells (CD45RO+), while the IgG1 portion binds to Fc receptors on cytotoxic cells (da Silva et al, 2002). Alefacept inhibits T-cell activation and proliferation, by interfering with the downstream activation of cytokines by interfering with the binding between CD2 on T lymphocytes and LFA-3 on antigen-presenting cells (da Silva et al, 2002). Since CD2 is highly expressed on CD45RO+ T cells, alefacept mainly inhibits memory-effector $\mathrm{T}$ cells, which represent the majority of $\mathrm{T}$ lymphocytes in psoriatic lesions, and preserves naïve cells 
(Krueger, 2002). Alefacept also causes the depletion of CD45RO+ memory $\mathrm{T}$ cells via cytotoxic cell-mediated apoptosis; this occurs between CD2 on target T lymphocytes and FC receptors, primarily Fc $\gamma$ RIII+, on natural killer cells and macrophages (Cooper et al, 2002). Alefacept was the first FDA-approved biologic agent in 2003 for the treatment of moderate to severe chronic plaque psoriasis in patients who are candidates for systemic treatment or phototherapy (Biogen Inc., 2003) but it is not currently approved for the treatment of psoriasis by EMA. It is also being investigated for the treatment of other conditions caused by T-cell dysregulation, such as psoriatic arthritis (Kraan et al, 2002; Mease \& Reich, 2009).

\subsubsection{Administration}

The recommended administration of alefacept is a once-weekly $15 \mathrm{mg}$ intramuscular injection (IM) for 12 weeks (Biogen Inc., 2003), although intravenous bolus injection (IV) has also been evaluated in several studies. A comparison of the pharmacokinetic and biologic activity of IM and IV administration showed that an adequate dose of IM alefacept leads to similar bioavailability and efficacy compared to IV administration and it is associated with minimal adverse effects (Vaishnaw \& TenHoor, 2002). Retreatment with an additional 12week course may be initiated if $\mathrm{CD} 4+\mathrm{T}$-lymphocyte counts are within the normal range, and a minimum of a 12-week interval has passed since the previous course of treatment (Biogen Inc., 2003).

\subsubsection{Clinical efficacy}

A series of clinical trials showed significant improvement in the PASI score in patients treated with alefacept. The first multicenter, randomized, controlled phase II trial was conducted in 229 patients who received alefacept $0.025,0.075$ and $0.150 \mathrm{mg} / \mathrm{kg}$ IV or placebo weekly for 12 weeks, with a 12-week follow-up (Ellis \& Krueger, 2001). Patients achieved a reduction in PASI by $38 \%, 53 \%$ and $53 \%$, respectively, compared with $21 \%$ reduction by placebo. A significant improvement in quality of life was also reported, and long-term follow-up showed a sustained response for a median of 10 months (Ellis \& Krueger, 2001).

Two phase III clinical trials showed similar results (Krueger et al, 2002; Lebwohl et al, 2003). In these trials, patients with chronic plaque psoriasis received a once-weekly administration of alefacept IV or IM for 12 weeks, with a 12-week follow-up. In the first study (Krueger et al, 2002), a total of 553 patients was randomized to receive $7.5 \mathrm{mg}$ of IV alefacept or placebo, while in the second trial (Lebwohl et al, 2003) 507 patients were treated with 10 or $15 \mathrm{mg}$ of IM alefacept or placebo. Both trials showed a significant clinical improvement in psoriatic patients: a PASI 75 was achieved by $28 \%$ in IV-treated patients compared to $8 \%$ in placebotreated patients, and by $28 \%$ and $33 \%$ in 10 or $15 \mathrm{mg}$ IM-treated patients, respectively, compared to $13 \%$ in the placebo group. Most responder patients maintained a $50 \%$ or greater reduction in PASI in the follow-up period. Other studies have been performed to investigate alefacept efficacy and safety in the long-term treatment of plaque psoriasis. Treatment of up to 5 courses provided incremental efficacy in responders, while maintaining the safety profile (Menter et al, 2006; Roberts et al, 2010). Although these studies are limited by the decreasing number of patients over multiple treatment courses or the lack of appropriate controls, but do they suggest that multiple courses of alefacept are well tolerated and maintain clinical improvement in responder patients. 
Several studies evaluated the effect of alefacept in combination with other therapies, including topical agents, methotrexate, cyclosporine, acitretin, systemic retinoids, or phototherapy (Krueger et al, 2008). The results suggest that the combination of alefacept with other psoriasis therapies is efficacious and well tolerated but larger studies are needed to confirm these results and evaluate long-term effects.

\subsubsection{Safety}

Alefacept is one of the safest biologic drugs for psoriasis. Clinical trials have demonstrated that it is well tolerated (Gottlieb, 2004; Krueger et al, 2002; Lebwohl et al, 2003; Roberts et al, 2010). The main concern is T lymphocyte depletion so that monitoring of CD4+ T cells is required during treatment and administration should be withheld if the CD4+ T-cell count falls below 250 cells/mL (Biogen Inc., 2003). The most common side effects are pharyngitis, headache, rhinitis, bronchitis and flu (Ellis \& Krueger, 2001; Gottlieb et al, 2003; Krueger et al, 2002; Lowe et al, 2003). These infections are not severe, and there is no evidence to date to suggest a predisposition to malignancies associated with alefacept.

\subsection{Abatacept}

Abatacept is a fusion protein composed of an Fc fragment of IgG1 and the extracellular domain of CTLA-4 (cytotoxic lymphocyte antigen-4) that inhibits T-cell costimulation. Abatacept is currently approved for the treatment of rheumatoid arthritis (Bristol-Myers Squibb, 2009). A phase II study has been terminated for psoriatic arthritis and it showed that $10 \mathrm{mg} / \mathrm{kg}$ may be an effective treatment (Mease et al, 2011).

\subsection{Rituximab}

Rituximab is a chimeric monoclonal antibody that selectively binds the CD20 antigen of B cells. Rituximab is currently used in the treatment of non Hodgkin's lymphoma and rheumatoid arthritis (Genentech USA, Inc., 2011). A phase I trial is ongoing to assess the efficacy and safety of rituximab in patients with psoriatic arthritis (Swedish Medical Center, 2009).

\section{IL-12/IL-23 inhibitors}

A third class of biologics classified as IL-12/IL-23 inhibitors has been developed for treating psoriasis. These two cytokines, mainly produced by activated dendritic cells, lead to differentiation of Th cells into the Th1 and Th17 subsets, respectively (Nestle et al, 2009). Moreover, elevated levels of IL-12 and IL-23 have been observed in psoriatic skin lesions (Yawalcar et al, 2009). Currently, ustekinumab is FDA- and EMA-approved for the treatment of chronic plaque psoriasis, whereas briakinumab, has recently had its approval application withdrawn in the US and Europe to conduct further analysis and clinical trials (Centocor Ortho Biotech, 2009; Kurzeia et al, 2011).

\subsection{Ustekinumab}

Ustekinumab is a fully human monoclonal antibody that binds to the p40 subunit that is shared by IL-12 and IL-23 (Centocor Ortho Biotech, 2009). IL-12 activates natural killer and T 
cell responses, including CD4+ T cell differentiation toward the Th1 phenotype, while IL-23 leads to Th17 differentiation, regulates $\mathrm{T}$ memory cells, and activates macrophages to maintain chronic autoimmune inflammation (Aggarwal et al, 2003; Trinchieri, 2003). Ustekinumab prevents the interaction of these cytokines with the IL-12R $\beta 1$ receptor, neutralizing their immune-mediated responses. A single administration of anti-IL-12p40 demonstrated significant changes in psoriatic skin lesions after 2 weeks, including the reduction of a type 1 cytokine (IFN- $\gamma$ ) and chemokines (IL-8, IFN- $\gamma$-inducible protein-10, and MCP-1), and a decrease of TNF $\alpha$ and infiltrating T cells (Toichi et al, 2006).

Ustekinumab was approved by the FDA in September 2009 for the treatment of adult patients with moderate-to-severe plaque psoriasis who are candidates for phototherapy or systemic therapy (Centocor Ortho Biotech, 2009). Early-stage clinical trials have also demonstrated its therapeutic potential in psoriatic arthritis (Gottlieb et al, 2009).

\subsubsection{Administration}

Ustekinumab is administered by subcutaneous injections at the recommended dose of $45 \mathrm{mg}$ for patients who weigh $\leq 100 \mathrm{~kg}$ and $90 \mathrm{mg}$ for those who weight $\geq 100 \mathrm{~kg}$, at week 0 and then at week 4 , followed by one injection every 12 weeks as maintenance treatment (Centocor Ortho Biotech, 2009). Clinical response to ustekinumab is associated with serum ustekinumab concentration and patient body weight. Two phase III clinical trials demonstrated that efficacy of the 45 and $90 \mathrm{mg}$ doses of ustekinumab was similar in patients weighing $\leq 100 \mathrm{~kg}$, while the $90 \mathrm{mg}$ dose was more effective than the $45 \mathrm{mg}$ dose in patients weighing >100 kg (Leonardi et al, 2008; Papp et al, 2008).

\subsubsection{Clinical efficacy}

The first phase II trial was performed in 320 patients with moderate-to-severe plaque psoriasis who were randomized to receive one of four subcutaneous dosing regimens of ustekinumab (one $45 \mathrm{mg}$ dose, one $90 \mathrm{mg}$ dose, 4-weekly $45 \mathrm{mg}$ doses, or 4-weekly $90 \mathrm{mg}$ doses) or placebo (Krueger et al, 2007). At week 12, a PASI 75 was achieved by 52\%, 59\%, $67 \%$, and $81 \%$, respectively, of the aforementioned groups, compared to $2 \%$ of placebo patients. Other measures of clinical outcome, including DLQI and Physician's Global Assessment (PGA) showed significant improvements in responders compared with placebo patients at both weeks 12 and 24. Two important clinical trials for the assessment of ustekinumab efficacy and safety are PHOENIX-1 and PHOENIX-2. Both are large-scale, randomized, placebo-controlled phase III trials designed to evaluate the efficacy and safety of ustekinumab in patients with moderate-to-severe plaque psoriasis over a period of five years. In the PHOENIX-1 study, 766 patients were randomized to subcutaneous injections of $45 \mathrm{mg}$ or $90 \mathrm{mg}$ of ustekinumab at weeks 0 and 4 and then every 12 weeks, or placebo at weeks 0 and 4, with crossover to ustekinumab at week 12 (Leonardi et al, 2008). At week 12, a PASI 75 was achieved by $67.1 \%, 66.4 \%$, and $3.1 \%$ of patients receiving $45 \mathrm{mg}, 90 \mathrm{mg}$ or placebo, respectively. Results at week 28 demonstrated durable effects of ustekinumab with $71.2 \%$ and $78.6 \%$ of patients treated with $45 \mathrm{mg}$ or $90 \mathrm{mg}$ achieving or maintaining a PASI 75 score. Patients that achieved PASI 75 were re-randomized to maintenance ustekinumab or withdrawal from treatment at week 40. A PASI 75 response was better maintained in patients receiving maintenance ustekinumab than in those who were withdrawn from 
treatment. The median time to loss of PASI 75 in patients withdrawn from therapy was 15 weeks. The PHOENIX-2 study enrolled 1230 patients (Papp et al, 2008). Its design and results were similar to the PHOENIX-1 study: a PASI 75 was achieved by $66.7 \%$ of patients in the $45 \mathrm{mg}$ group, by $75.7 \%$ in the $90 \mathrm{mg}$ group, by $3.7 \%$ in the placebo group, at week 12 . However, a dosing intensification was added for those subjects who did not respond fully to ustekinumab (PASI 50 to $<75$ ). At week 28, partial responders were re-randomized to continue dosing regimen every 12 weeks or to increase dosing frequency to every 8 weeks. In the $90 \mathrm{mg}$ group, 22 of 33 partial responders achieved PASI 75 after increasing dosage frequency to every 8 weeks. Conversely, dosing intensification did not improve clinical outcomes in the $45 \mathrm{mg}$ group. The authors concluded that intensification of dosing to once every 8 weeks with ustekinumab $90 \mathrm{mg}$ might be necessary to achieve a full response in partial responders. The ACCEPT study is a randomized phase III clinical trial that directly compares ustekinumab to etanercept in 903 patients with psoriasis (Griffiths et al, 2010). Patients were randomized to receive ustekinumab 45 or $90 \mathrm{mg}$ at week 0 and 4 , or etanercept $50 \mathrm{~g}$ twice weekly for 12 weeks. At week 12 PASI 75 was achieved by $74 \%$ of the patients in the ustekinumab $90 \mathrm{mg}$ group, by $68 \%$ of patients in the ustekinumab $45 \mathrm{mg}$ group, and by $57 \%$ of those in the etanercept group. Patients who were unresponsive to etanercept were switched to ustekinumab, with almost a $50 \%$ response rate within the first 12 weeks. There were no significant safety differences between ustekinumab and etanercept in the ACCEPT trial. Both drugs were generally well tolerated. This head-to-head comparison clearly showed a significant superiority of ustekinumab over etanercept for the treatment of patients with moderate-to-severe psoriasis. However, this trial only evaluated 12 weeks of therapy, a short period to have an adequate comparison of the drugs, especially for their safety profiles.

\subsubsection{Safety}

In general, ustekinumab is well tolerated with only mild adverse events experienced in clinical trials. The most common adverse events have been equally observed between the treatment and placebo groups and included upper respiratory infections, headache, nasopharyngitis, arthralgia, back pain, and injection site reactions (Leonardi et al, 2008; Papp et al, 2008). Safety concerns exist for risks of infection and suppression of tumor immune surveillance. Individuals congenitally deficient in IL-12p40 or IL-12R $\beta 1$ are known to have an increased susceptibility to intracellular pathogens, including tuberculosis and salmonella (Döffinger et al, 2002). However, in the PHOENIX 1 and 2 studies only two serious infections occurred in the ustekinumab group treated with the $90 \mathrm{mg}$ dose. No mycobacterial or salmonella infections were reported. The risk of malignancy did not appear to be significant. Cutaneous malignancies were reported in two patients in the PHOENIX 2 study, a squamous cell carcinoma in the placebo group and a basal cell carcinoma in the 90 mg treatment group. No malignancies were reported in the PHOENIX 1 trial. The rate of malignancies reported in ustekinumab-treated patients was comparable to the rate in the general population. Patients with psoriasis have an increased risk of cardiovascular events. In the phase II trial of ustekinumab two patients experienced myocardial infarction and one suffered a stroke (Krueger et al, 2007). However, subsequent larger phase III studies revealed no apparent increased risk of cardiovascular side effects. Further studies are needed to assess long-term ustekinumab safety in patients treated for extended periods. 


\subsection{Briakinumab}

Briakinumab is a recombinant fully human IgG1 monoclonal antibody directed against the shared p40 subunit of IL-12 and IL-23 (Kimball et al, 2008). Due to its binding to the aforesaid cytokines, briakinumab causes a decrease in secretion of IL-6, IL-12, INF- $\gamma$ and TNF $\alpha$, as demonstrated in patients with Crohn's disease (Ding et al, 2008). In a phase II study, 180 patients suffering from psoriasis were treated with placebo or briakinumab at one of the following doses: one $200 \mathrm{mg}$ dose at week $0,100 \mathrm{mg}$ eow for 12 weeks, $200 \mathrm{mg}$ weekly for 4 weeks, $200 \mathrm{mg}$ eow for 12 weeks, $200 \mathrm{mg}$ weekly for 12 weeks. At week 12, an improvement in PASI 75 was reported for all briakinumab-treated groups compared with placebo (Kimball et al, 2008). The retreatment efficacy and the long-term safety of briakinumab through 48 weeks have been evaluated by the same authors (Kimball et al, 2009). Kimball et al. reported that the efficacy of briakinumab was higher in the first 12 weeks compared with the re-treatment phase, although more patients showed a PASI 75 response during this period. The most frequent adverse events observed during the treatment with briakinumab were injection site reactions, upper respiratory infections and nasopharyngitis.

\section{Perspectives}

In the last decade, the detailed comprehension of the molecular mechanisms involved in psoriasis has led to the development of new biological drugs, such as monoclonal antibodies, recombinant proteins and small RNA drugs, which are currently under evaluation for psoriasis and/or psoriatic arthritis.

\subsection{Anti-interleukin 17}

IL-17 is a pro-inflammatory cytokine produced by Th17 T cells, one of the key players in the pathogenesis of psoriasis. Due to its role in psoriasis, IL-17 is a new emerging target for biological therapy.

AMG 827 is a fully human IgG2 anti IL-17 receptor monoclonal antibody investigated in phase II trials for psoriasis, rheumatoid arthritis and Crohn's disease (Amgen, 2011). Preliminary data from a small study showed that psoriatic patients treated with $700 \mathrm{mg}$ AMG 827 IV had a significant improvement in terms of histopathological features and PASI score (Russell et al, 2010).

AIN457 is a recombinant fully human anti-IL-17 monoclonal antibody that selectively binds and neutralizes IL-17. The efficacy and safety of AIN457 has been evaluated in a phase II trial (Jancin, 2009) which enrolled 36 patients suffering from chronic plaque psoriasis. A PASI 75 response was observed in $44 \%$ of patients receiving $3 \mathrm{mg} / \mathrm{kg}$ AIN457 IV compared with $9 \%$ of placebo group. AIN457 is currently undergoing phase II studies for psoriasis, psoriatic arthritis and rheumatoid arthritis and a phase III study for uveitis (Novartis, 2010).

LY2439821 is a new humanized IgG4 anti-IL-17 monoclonal antibody in a phase II trial for psoriasis and rheumatoid arthritis (Eli Lilly and Company, 2011).

\subsection{Anti-interleukin 22}

IL-22 is a pro-inflammatory cytokine produced by both Th17 and a new group of T cells known as Th22 cells; Th22 cells are known to induce epidermal hyperplasia and dermal 
inflammation via several transcription factors such as STAT3 (Nograles et al, 2009). ILV-094 is a fully human anti IL-22 monoclonal antibody. A phase I study to evaluate the efficacy and safety of ILV-094 in psoriasis has been recently completed, while it is currently ongoing a phase II trial for rheumatoid arthritis (Pfizer, 2010).

\subsection{Chaperonin 10}

Chaperonin 10 belongs to the heat shock proteins family and acts as a molecular chaperon, regulating protein folding. Several studies support its anti-inflammatory activity and its role in down-regulating the excessive immune response (van Eden, 2008). Recombinant Chaperonin 10 (Cpn10) mimics these activities and its efficacy in psoriasis has been evaluated by a single-center, double-blind exploratory study, showing a significant improvement in Cpn10-treated patients (Williams et al, 2008). Phase II trials have been completed for psoriasis, rheumatoid arthritis and multiple sclerosis (Golant \& GutmanYassky, 2011).

\subsection{Small RNA drugs}

The use of RNA interference as a drug is one of the possible therapeutic strategies to target the pro-inflammatory cytokines involved in psoriasis, as shown by several phase I and II ongoing clinical trials (reviewed in Jackson et al, 2006). On the basis of their role in psoriasis, suitable mRNA targets are TNF $\alpha$, IL-20 and IL-23. A recent study showed that local small RNA therapy against $\mathrm{TNF} \alpha$ provided amelioration in psoriasis in a xenograft transplantation model (Jakobsen et al, 2009). These results indicate that RNA interference is a potential therapy in the treatment of inflammatory skin diseases. Nevertheless the main challenge for this kind of therapy remains the delivery of small RNA.

\section{Conclusion}

The introduction of biological drugs in clinical practice has revolutionized the treatment of psoriasis and psoriatic arthritis in the last decade. Biologics have shown to be effective and to have an acceptable safety profile, but there is still a need to assess long-term toxicity through clinical experience and careful post-marketing surveillance.

\section{References}

Abbott Laboratories. (March, 2011). HUMIRA package insert Abbott Laboratories. In: www.humira.com, 28.05.2011, available from: http://www.rxabbott.com/pdf/humira.pdf.

Aggarwal, S., Ghilardi, N., Xie, M.H., de Sauvage, F.J. \& Gurney, A.L. (2003). Interleukin-23 promotes a distinct CD4 $\mathrm{T}$ cell activation state characterized by the production of interleukin-17. The Journal of Biological Chemistry, Vol.278, No.3, pp.1910-1914.

Amgen , Inc. (2011). Pipeline. In: www.amgen.com, 28.05.2011, available from: http://www.amgen.com/science/pipe.html

Amgen, Inc. (February, 2011). Enbrel package Insert. In: www.enbrel.com, 28.05.2011, available from: http://pi.amgen.com/united_states/enbrel/derm/enbrel_pi.pdf. 
Antiga, E., Volpi, W., Chiarini, C., Cardilicchia, E., Filì, L., Manuelli, C., Parrochi, P., Fabbri, P. \& Caproni, M. (2010). The role of etanercept on the expression of markers of T helper 17 cells and their precursors in skin lesions of patients with psoriasis vulgaris. International Journal of Immunopathology and Pharmacology, Vol.23, No.3, pp.767-774.

Antoni, C., Kavanaugh, A., Kirkham, B., Tutuncu, Z., Burmester, G.R., Schneider, U., Furst, D.E., Molitor, J., Keystone, E., Gladman, D., Manger, B., Wassenberg, S., Weier, R., Wallace, D.J., Weisman, M.H., Kalden, J.R. \& Smolen, J. (2005a). Sustained benefits of infliximab therapy for dermatologic and articular manifestations of psoriatic arthritis: results from the infliximab multinational psoriatic arthritis controlled trial (IMPACT). Arthritis and Rheumatism, Vol.52, No.4, pp.1227-1236.

Antoni, C., Krueger, G.G., de Vlam, K., Birbara, C., Beutler, A., Guzzo, C., Zhou, B., Dooley, L.T. \& Kavanaugh, A. (2005b). Infliximab improves signs and symptoms of psoriatic arthritis: results of the IMPACT 2 trial. Annals of the Rheumatic Diseases, Vol.64, No.8, pp.1150-1157.

Antoni, C.E., Kavanaugh, A., van der Heijde, D., Beutler, A., Keenan, G., Zhou, B., Kirkham, B., Tutuncu, Z., Burmester, G.R., Schneider, U., Furst, D., Molitor, J., Keystone, E., Gladman, D.D., Manger, B., Wassenberg, S., Weier, R., Wallace, D.J., Weisman, M.H., Kalden, J.R. \& Smolen, J.S. (2008). Two-year efficacy and safety of infliximab treatment in patients with active psoriatic arthritis: findings of the Infliximab Multinational Psoriatic Arthritis Controlled Trial (IMPACT). The Journal of Rheumatology, Vol.35, No.5, pp.869-876.

Bachmann, F., Nast, A., Sterry, W. \& Philipp, S. (2010). Safety and efficacy of the tumor necrosis factor antagonists. Seminars in Cutaneous Medicine and Surgery, Vol.29, No.1, pp.35-47.

Bagel, J. (2011). Adalimumab plus narrowband ultraviolet B light phototherapy for the treatment of moderate to severe psoriasis. Journal of Drugs Dermatology, Vol.10, No.4, pp.366-371.

Bartelds, G.M., Wijbrandts, C.A., Nurmohamed, M.T., Stapel, S., Lems, W.F., Aarden, L., Dijkmans, B.A., Tak, P.P. \& Wolbink, G.J. (2010). Anti-infliximab and antiadalimumab antibodies in relation to response to adalimumab in infliximab switchers and anti-tumour necrosis factor naive patients: a cohort study. Annals of the Rheumatic Diseases, Vol.69, No.5, pp.817-821.

Biogen, Inc. (2003). Amevive package insert. In: www.clinicaltrials.gov, 28.05.2011, available from: http://www.fda.gov/downloads/Drugs/DevelopmentApprovalProcess/HowDrugsare DevelopedandApproved/ApprovalApplications/TherapeuticBiologicApplications/ucm08600 9.pdf.

Boehncke, W.H. (2007). Efalizumab in the treatment of psoriasis. Biologics, Vol.1, No.3, pp. 301-309.

Brennan, F.M., Chantry, D., Jackson, A., Maini, R. \& Feldmann M. (1989). Inhibitory effect of TNF alpha antibodies on synovial cell interleukin-1 production in rheumatoid arthritis. The Lancet, Vol.2, No.8657, pp.244-247.

Bristol-Myers Squibb. (August, 2009). Orencia package insert. In: www.orencia.com,

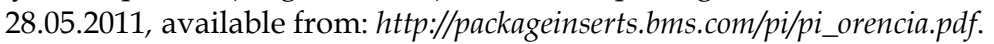


Cassano, N., Loconsole, F., Galluccio, A., Miracapillo, A., Pezza, M. \& Vena, G.A. (2006). Once-weekly administration of high-dosage Etanercept in patients with plaque psoriasis: results of a pilot experience (power study). International Journal of Immunopathology and Pharmacology, Vol.19, No.1, pp.225-229.

Cassano, N., Loconsole, F., Miracapillo, A., Travaglini, M., Di Giuseppe, M.D., Congedo, M., Galluccio, A., Buquicchio, R., Mastrandrea, V., Filieri, M., Raho, G., Pezza, M. \& Vena, G.A. (2010). The role of etanercept on the expression of markers of T helper 17 cells and their precursors in skin lesions of patients with psoriasis vulgari Treatment of psoriasis with different dosage regimens of etanercept: preliminary results from the Taranta Plastic Study Groups. International Journal of Immunopathology and Pharmacology, Vol.23, No.3, pp.797-802.

Centocor Ortho Biotech, Inc. (2009). Stelara medication label. In: www.fda.gov, 28.05.2011, available from: http://www.accessdata.fda.gov/drugsatfda_docs/label/2009/125261lbl.pdf.

Centocor Ortho Biotech, Inc. (December, 2010). Simponi package insert. In: www.simponi.com, 28.05.2011, available from:

http://www.simponi.com/sites/default/files/pdf/prescribing-information.pdf.

Centocor Ortho Biotech, Inc. (February, 2011). Remicade package insert. In: www.remicade.com, 28.05.2011, available from:

http://www.remicade.com/remicade/assets/hcp_ppi.pdf.

Chaudhari, U., Romano, P., Mulcahy, L.D., Dooley, L.T., Baker, D.G. \& Gottlieb, A.B. (2001). Efficacy and safety of infliximab monotherapy for plaque-type psoriasis: a randomised trial. The Lancet, Vol.357, No.9271, pp.1842-1847.

Chung, E.S., Packer, M., Lo, K.H., Fasanmade, A.A. \& Willerson, J.T. (2009). Randomized, double-blind, placebo-controlled, pilot trial of infliximab, a chimeric monoclonal antibody to tumor necrosis factor-alpha, in patients with moderate-to-severe heart failure: results of the anti-TNF Therapy Against Congestive Heart Failure (ATTACH) trial. Circulation, Vol.107, No.25, pp.3133-3140.

Cooper, J.C., Morgan, G., Harding, S., Subramanyam, M., Majeau, G.R., Moulder, K. \& Alexander, D.R. (2003). Alefacept selectively promotes NK cell-mediated deletion of CD45R0+ human T cells. European Journal of Immunology, Vol.33, No.3, pp.666675.

da Silva, A.J., Brickelmaier, M., Majeau, G.R., Li, Z., Su, L., Hsu, Y.M. \& Hochman, P.S. (2002). Alefacept, an immunomodulatory recombinant LFA-3/IgG1 fusion protein, induces CD16 signaling and CD2/CD16-dependent apoptosis of CD2(+) cells. Immunology, Vol.168, No.9, pp.4462-4471.

Dauden, E., Griffiths, C., Ortonne, J.P., Kragballe, K., Molta, C.T., Robertoson, D., Pedersen, R., Estojak, J. \& Boggs, R. (2009). Improvements in patient-reported outcomes in moderate-to-severe psoriasis patients receiving continuous or paused etanercept treatment over 54 weeks: the CRYSTEL study. Journal of the European Academy of Dermatology and Venereology, Vol.23, No.12, pp.1374-82.

de Groot, M., Teunissen, M.B.M., Picavet, D.I., de Rie, M.A. \& Bos, J.D. (2010). Reduction of different inflammatory cell types of the innate immune system in psoriatic skin during etanercept treatment. Experimental Dermatology, Vol.19, pp.754-756. 
De Pità, O., Nardis, C., Lupi, F., Luci, C.A., Frezzolini, A. \& Pallotta, S. (2011). Modulation of Toll-like receptors in psoriatic patients during therapy with adalimumab. International Journal of Immunopathology and Pharmacology, Vol.24, No.1, pp.185-188.

Ding, C., Xu, J. \& Li, J. (2008). ABT-874, a fully human monoclonal anti-IL-12/IL-23 antibody for the potential treatment of autoimmune diseases. Current Opinion in Investigational Drugs, Vol. 9, No.5, pp.515-522.

Dixon, W.G., Watson, K., Lunt, M., Hyrich, K.L., Silman, A.J. \& Symmons, D.P. (2006). Rates of serious infection, including site-specific and bacterial intracellular infection, in rheumatoid arthritis patients receiving anti-tumor necrosis factor therapy: results from the British Society for Rheumatology Biologics Register. Arthritis and Rheumatism, Vol.54, No.8, pp.2368-2376.

Döffinger, R., Dupuis, S., Picard, C., Fieschi, C., Feinberg, J., Barcenas-Morales, G. \& Casanova, J.L. (2002). Inherited disorders of IL-12- and IFNgamma-mediated immunity: a molecular genetics update. Molecular Immunology, Vol.38, No.12-13, pp.903-909.

Eli Lilly and Company. (April, 2011). A Study in Patients With Moderate to Severe Psoriasis. In:www.clinicaltrials.gov,28.05.2011, available from:

http://clinicaltrials.gov/ct2/show/NCT01107457?term=LY2439821\&rank=3.

Ellis, C.N. \& Krueger, G.G. (2001). Treatment of chronic plaque psoriasis by selective targeting of memory effector $\mathrm{T}$ lymphocytes. New England Journal of Medicine, Vol.345, No.4, pp.248-255.

Esposito, M., Giunta, A., Mazzotta, A., Babino, G., Talamonti, M., Chimenti, M.S. \& Chimenti, S. (2010). Continuous treatment of plaque-type psoriasis with etanercept: an observational long-term experience. International Journal of Immunopathology and Pharmacology, Vol.23, No.2, pp.503-509.

Feldman, S.R., Gordon, K.B., Bala, M., Evans, R., Li, S., Dooley, L.T., Guzzo, C., Patel, K., Menter, A. \& Gottlieb, A.B. (2005). Infliximab treatment results in significant improvement in the quality of life of patients with severe psoriasis: a double-blind placebo-controlled trial. The British Journal of Dermatology, Vol.152, No.5, pp.954960.

Foley, P.A., Quirk, C., Sullivan, J.R., Dolianitis, C., Hack, S.P., Thirunavukkarasu, K. \& Cooper, J. (2010). Combining etanercept with traditional agents in the treatment of psoriasis: a review of the clinical evidence. Journal of the European Academy of Dermatology and Venereology, Vol.24, pp.1135-1143.

Genentech USA, Inc. (April, 2011). Rituxan package insert. In:www.rituxan.com, 28.05.2011, available from: http://www.gene.com/gene/products/information/pdf/rituxan-prescribing.pdf.

Genentech, Inc. (2009). Voluntary U.S. market withdrawal of Raptiva® (efalizumab). In: www.fda.gov, 28.05.2011, available from:

http://www.fda.gov/downloads/Safety/MedWatch/SafetyInformation/SafetyAlertsforHuman MedicalProducts/UCM149681.pdf.

Genovese, M.C., Mease, P.J., Thomson, G.T., Kivitz, A.J., Perdok, R.J., Weinberg, M.A., Medich, J. \& Sasso, E.H. (2007). Safety and efficacy of adalimumab in treatment of patients with psoriatic arthritis who had failed disease modifying antirheumatic drug therapy. The Journal of Rheumatology, Vol.34, No.5, pp.1040-1050. 
Gerdes, S. \& Mrowietz, U. (2009). Impact of comorbidities on the management of psoriasis. Current Problems in Dermatology, Vol.38, pp.21-36.

Gisondi, P., Gubinelli, E., Cocuroccia, B. \& Girolomoni, G. (2004). Targeting tumor necrosis factor-alpha in the therapy of psoriasis. Current Drug Targets - Inflammation $\mathcal{E}$ Allergy, Vol.3, No.2, pp.175-183.

Gladman, D.D., Mease, P.J., Ritchlin, C.T., Choy, E.H., Sharp, J.T., Ory, P.A., Perdok, R.J. \& Sasso, E.H. (2007). Adalimumab for long-term treatment of psoriatic arthritis: fortyeight week data from the adalimumab effectiveness in psoriatic arthritis trial. Arthritis \& Rheumatism, Vol.56, No.2, pp.476-488.

Golant, A.K. \& Guttman-Yassky, B.S.E. (2011). Psoriasis Treatments: A review of the current research pipeline. Psoriasis Forum, Vol.17, No.1, pp.11-23.

Gordon, K.B., Gottlieb, A.B., Leonardi, C.L., Elewski, B.E., Wang, A., Jahreis, A. \& Zitnik, R. (2006a). Clinical response in psoriasis patients discontinued from and then reinitiated on Etanercept therapy. Journal of Dermatological Treatment, Vol.17, No.1, pp. 9-17.

Gordon, K.B., Langley, R.G., Leonardi, C., Toth, D., Menter, M.A., Kang, S., Heffernan, M., Miller, B., Hamlin, R., Lim, L., Zhong, J., Hoffman, R. \& Okun, M.M. (2006b). Adalimumab therapy for moderate to severe psoriasis: A randomized, controlled phase III trial. Journal of American Academy of Dermatology, Vol.55, No.4, pp.598-606.

Gottlieb, A.B., Krueger, J.G., Wittkowski, K., Dedrick, R., Walicke, P.A. \& Garovoy, M. (2002). Psoriasis as a model for T-cell-mediated disease: immunobiologic and clinical effects of treatment with multiple doses of efalizumab, an anti-CD11a antibody. Archives of Dermatology, Vol.138, No.5, pp. 591-600.

Gottlieb A.B., Matheson, R.T., Lowe, N., Krueger, G.G., Kang, S., Goffe, B.S., Gaspari, A.A., Ling, M., Weinstein, G.D., Nayak, A., Gordon, K.B. \& Zitnik, R. (2003). A randomized trial of etanercept as monotherapy for psoriasis. Archives of Dermatology, Vol.139, No.12, pp.1627-1632.

Gottlieb, A.B., Evans, R., Li, S., Dooley, L.T., Guzzo, C.A., Baker, D., Bala, M., Marano, C.W. \& Menter, A. (2004). Infliximab induction and maintenance therapy for moderateto-severe psoriasis: a phase III, multicenter, double-blind trial. Journal of American Academy of Dermatology, Vol.51, No.4, pp.534-542.

Gottlieb, A., Menter, A., Mendelsohn, A., Shen, Y.K., Li, S., Guzzo, C., Fretzin, S., Kunynetz, R. \& Kavanaugh, A. (2009). Ustekinumab, a human interleukin 12/23 monoclonal antibody, for psoriatic arthritis: randomised, double-blind, placebo-controlled, crossover trial. The Lancet, Vol.373, No.9664, pp.633-640.

Griffiths, C.E., Strober, B.E., van de Kerkhof, P., Ho, V., Fidelus-Gort, R., Yeilding, N., Guzzo, C., Xia, Y., Zhou, B., Li, S., Dooley, L.T., Goldstein, N.H. \& Menter, A. (2010). Comparison of ustekinumab and etanercept for moderate-to-severe psoriasis. New England Journal of Medicine, Vol.362, No.2, pp.118-128.

Haraoui, B., Cameron, L., Ouellet, M. \& White, B. (2006). Anti-infliximab antibodies in patients with rheumatoid arthritis who require higher doses of infliximab to achieve or maintain a clinical response. Journal of Rheumatology, Vol.33, No.1, pp.3136.

Heiberg, M.S., Koldingsnes, W., Mikkelsen, K., Rødevand, E., Kaufmann, C., Mowinckel, P. \& Kvien, T.K. (2008). The comparative one-year performance of anti-tumor necrosis 
factor alpha drugs in patients with rheumatoid arthritis, psoriatic arthritis, and ankylosing spondylitis: results from a longitudinal, observational, multicenter study. Arthritis and Rheumatism, Vol.59, No.2, pp.234-240.

Jackson, A.L., Burchard, J., Schelter, J., Chau, B.N., Cleary, M., Lim, L. \& Linsley, P.S. (2006). Widespread siRNA "off-target" transcript silencing mediated by seed region sequence complementarity. RNA, Vol. 12, No.7, pp.1179-1187.

Jakobsen, M., Stenderup, K., Rosada, C., Moldt, B., Kamp, S., Dam, T.N., Jensen, T.G. \& Mikkelsen, J.G. (2009). Amelioration of psoriasis by anti-TNF-alpha RNAi in the xenograft transplantation model. Molecular Therapy, Vol. 17, No.10, pp.1743-1753.

Jancin, B. (2009). IL-17A Blocker Shows Early Promise for Psoriasis. Skin and Allergy News, Vol.40, No.11, pp.5.

Kavanaugh, A., Krueger, G.G., Beutler, A., Guzzo, C., Zhou, B., Dooley, L.T., Mease, P.J., Gladman, D.D., de Vlam, K., Geusens, P.P., Birbara, C., Halter, D.G. \& Antoni, C. (2007). Infliximab maintains a high degree of clinical response in patients with active psoriatic arthritis through 1 year of treatment: results from the IMPACT 2 trial. Annals of the Rheumatic Diseases, Vol.66, No.4, pp.498-505.

Kavanaugh, A., McInnes, I., Mease, P., Krueger, G.G., Gladman, D., Gomez-Reino, J., Papp, K., Zrubek, J., Mudivarthy, S., Mack, M., Visvanathan, S. \& Beutler, A. (2009a). Golimumab, a new human tumor necrosis factor alpha antibody, administered every four weeks as a subcutaneous injection in psoriatic arthritis: Twenty-fourweek efficacy and safety results of a randomized, placebo-controlled study. Arthritis and Rheumatism, Vol.60, No.4, pp.976-986.

Kavanaugh, A., Mease, P., Krueger, G.G. et al. (2009b). Golimumab, a new human TNF alpha antibody, administered subcutaneously every 4 week in psoriatic arthritis patients: 104-week efficacy and safety results of the randomized, placebocontrolled GO-REVEAL study. Abstract presented at the 2009 European League Against Rheumatism (EULAR) Annual Congress. June 10-13, Copenhagen.

Kerbleski, J.F. \& Gottlieb, A.B. (2011). Dermatological complications and safety of anti-TNF treatments. Gut, Vol.58, No.8, pp.1033-1039.

Kimball, A.B., Gordon, K.B., Langley, R.G., Menter, A., Chartash, E.K. \& Valdes, J. (2008). Safety and efficacy of ABT-874, a fully human interleukin 12/23 monoclonal antibody, in the treatment of moderate to severe chronic plaque psoriasis: results of a randomized, placebo-controlled, phase 2 trial. Archives of Dermatology, Vol. 144, No.2, pp.200-207.

Kimball, A.B., J. Zhong, J., Valdes, J.M. \& Gordon, K. (2009). Retreatment efficacy and longterm safety of the fully human, interleukin-12/23 monoclonal antibody ABT-874 in the treatment of moderate to severe psoriasis: 48 week results from a phase II trial to severe psoriasis: 48 week results from a phase II trial. Journal of the American Academy of Dermatology Vol.60, Ab.168, San Francisco, 67th Annual Meeting of the American Academy of Dermatology (AAD), March 6-10.

Klotz, U., Teml, A. \& Schwab, M. (2007). Clinical pharmacokinetics and use of infliximab. Clinical Pharmacokinetics, Vol.46, No.8, pp.645-660.

Ko, J.M., Gottlieb, A.B. \& Kerbleski, J.F. (2009). Induction and exacerbation of psoriasis with TNF-blockade therapy: a review and analysis of 127 cases. Journal of Dermatological Treatement, Vol.20, No.2, pp.100-108. 
Kothary, N., Diak, I.L., Brinker, A., Bezabeh, S., Avigan, M. \& Pan, G.D. (2011). Progressive multifocal leukoencephalopathy associated with efalizumab use in psoriasis patients. Journal of American Academy of Dermatology, 21 April.

Kraan, M.C., van Kuijk, A.W., Dinant, H.J., Goedkoop, A.Y., Smeets, T.J., de Rie, M.A., Dijkmans, B.A., Vaishnaw, A.K., Bos, J.D. \& Tak, P.P. (2002). Alefacept treatment in psoriatic arthritis: reduction of the effector $\mathrm{T}$ cell population in peripheral blood and synovial tissue is associated with improvement of clinical signs of arthritis. Arthritis \& Rheumatism, Vol.46, No.10, pp.2776-2784.

Krueger, G.G. (2002). Selective targeting of T cell subsets: focus on alefacept - a remittive therapy for psoriasis. Expert Opinion on Biological Therapy, Vol.2, No.4, pp.431-441.

Krueger, G.G., Papp, K.A., Stough, D.B., Loven, K.H., Gulliver, W.P. \& Ellis, C.N. (2002). A randomized, double-blind, placebo-controlled phase III study evaluating efficacy and tolerability of 2 courses of alefacept in patients with chronic plaque psoriasis. Journal of American Academy of Dermatology, Vol.47, No.6, pp.821-833.

Krueger, G.G., Langley, R.G., Leonardi, C., Yeilding, N., Guzzo, C., Wang, Y., Dooley, L.T. \& Lebwohl, M. (2007). A human interleukin-12/23 monoclonal antibody for the treatment of psoriasis. The New England Journal of Medicine, Vol.356, No.6, pp.580592.

Krueger, G.G., Gottlieb, A.B., Sterry, W., Korman, N. \& Van De Kerkhof, P. (2008). A multicenter, open-label study of repeat courses of intramuscular alefacept in combination with other psoriasis therapies in patients with chronic plaque psoriasis. The Journal of Dermatological Treatment, Vol.19, No.3, pp.146-155.

Kunz M. (2009). Current treatment of psoriasis with biologics. Current Drug Discovery Technologies, Vol.6, No.4, pp.231-240.

Kurzeja, M., Rudnicka, L. \& Olszewska, M. (2011). New interleukin-23 pathway inhibitors in dermatology: ustekinumab, briakinumab, and secukinumab. Am J Clin Dermatol. Vol.12, No.2, pp.113-125.

Lebwohl, M., Christophers, E., Langley, R., Ortonne, J.P., Roberts, J. \& Griffiths, C.E. (2003). An international, randomized, double-blind, placebo-controlled phase 3 trial of intramuscular alefacept in patients with chronic plaque psoriasis. Archives of Dermatology, Vol.139, No.6, pp.719-727.

Leman, J. \& Burden, A. (2008). Treatment of severe psoriasis with infliximab. Journal of Therapeutics and Clinical Risk Management, Vol.4, No.6, pp.1165-1175.

Leonardi, C.L., Powers, J.L., Matheson, R.T., Goffe, B.S., Zitnik, R., Wang, A. \& Gottlieb, A.B. (2003). Etanercept as monotherapy in patients with psoriasis. The New England Journal of Medicine, Vol.349, No.21, pp.2014-2022.

Leonardi, C.L., Kimball, A.B., Papp, K.A., Yeilding, N., Guzzo, C., Wang, Y., Li, S., Dooley, L.T. \& Gordon, K.B. (2008). Efficacy and safety of ustekinumab, a human interleukin-12/23 monoclonal antibody, in patients with psoriasis: 76-week results from a randomised, double-blind, placebo-controlled trial (PHOENIX 1). The Lancet, Vol.371, No.9625, pp.1665-1674.

Leonardi, C., Strober, B., Gottlieb, A.B., Elewski, B.E., Ortonne, J.P., van de Kerkhof, P., Chiou, C.F., Dunn, M. \& Jahreis, A. (2010). Long-term safety and efficacy of etanercept in patients with psoriasis: an open-label study. Journal of Drugs in Dermatology, Vol.9, No.8, pp.928-937. 
Lowes, M.A., Chamian, F., Abello, M.V., Fuentes-Duculan, J., Lin, S.L., Nussbaum, R., Novitskaya, I., Carbonaro, H., Cardinale, I., Kikuchi, T., Gilleaudeau, P., SullivanWhalen, M., Wittkowski, K.M., Papp, K., Garovoy, M., Dummer, W., Steinman, R.M. \& Krueger, J.G. (2005). Increase in TNF-alpha and inducible nitric oxide synthase-expressing dendritic cells in psoriasis and reduction with efalizumab (anti-CD11a). Proceedings of the National Academy of Sciences, Vol.102, No.52, pp. 19057-19062.

Lowes, M.A., Kikuchi, T., Fuentes-Duculan, J., Cardinale, I., Zaba, L.C., Haider, A.S., Bowman, E.P. \& Krueger, J.G. (2008). Psoriasis vulgaris lesions contain discrete populations of Th1 and Th17 T cells. The Journal of Investigative Dermatology, Vol.128, No.5, pp.1207-1211.

Malaviya, R., Sun, Y., Tan, J.K., Wang, A., Magliocco, M., Yao, M., Krueger, J.G. \& Gottlieb, A.B. (2006). Etanercept induces apoptosis of dermal dendritic cells in psoriatic plaques of responding patients. Journal of the American Academy of Dermatology, Vol.55, No.4, pp.590-597.

Mease, P.J., Goffe, B.S., Metz, J., VanderStoep, A., Finck, B. \& Burge, D.J. (2000). Etanercept in the treatment of psoriatic arthritis and psoriasis: a randomised trial. The Lancet, Vol.356, No.9227, pp.385-390.

Mease, P.J., Kivitz, A.J., Burch, F.X., Siegel, E.L., Cohen, S.B., Ory, P., Salonen, D., Rubenstein, J., Sharp, J.T. \& Tsuji, W. (2004). Etanercept treatment of psoriatic arthritis: safety, efficacy, and effect on disease progression. Arthritis \& Rheumatism, Vol.50, No.7, pp.2264-2272.

Mease, P.J., Gladmanm D.D., Ritchlinm C.T., Rudermanm E.M., Steinfeldm S.D., Choy, E.H., Sharp, J.T., Ory, P.A., Perdok, R.J. \& Weinberg, M.A. (2005). Adalimumab for the treatment of patients with moderately to severely active psoriatic arthritis: results of a double-blind, randomized, placebo-controlled trial. Arthritis $\mathcal{E}$ Rheumatism, Vol.52, No.10, pp.3279-3289.

Mease, P.J., Ory, P., Sharp, J.T., Ritchlin, C.T., Van den Bosch, F., Wellborne, F., Birbara, C., Thomson, G.T., Perdok, R.J., Medich, J., Wong, R.L. \& Gladman, D.D. (2009). Adalimumab for long-term treatment of psoriatic arthritis: 2-year data from the Adalimumab Effectiveness in Psoriatic Arthritis Trial (ADEPT). Annals of the Rheumatic Diseases, Vol.68, No.5, pp.702-709.

Mease, P.J. \& Reich, K. (2009). Alefacept with methotrexate for treatment of psoriatic arthritis: open-label extension of a randomized, double-blind, placebo-controlled study. Journal of American Academy of Dermatology, Vol.60, No.3, pp.402-411.

Mease, P.J., Woolley, J.M., Singh, A., Tsuji, W., Dunn, M. \& Chiou, C.F. (2010). Patientreported outcomes in a randomized trial of etanercept in psoriatic arthritis. The Journal of Rheumatology, Vol.37, No.6, pp.1221-1227.

Mease, P., Genovese, M.C., Gladstein, G., Kivitz, A.J., Ritchlin, C., Tak, P.P., Wollenhaupt, J., Bahary, O., Becker, J.C., Kelly, S., Sigal, L., Teng, J. \& Gladman, D. (2011). Abatacept in the treatment of patients with psoriatic arthritis: results of a six-month, multicenter, randomized, double-blind, placebo-controlled, phase II trial. Arthritis and Rheumatism, Vol. 63, No.4, pp.939-948. 
Menter, A., Cather, J.C., Baker, D., Farber, H.F., Lebwohl, M. \& Darif, M. (2006). The efficacy of multiple courses of alefacept in patients with moderate to severe chronic plaque psoriasis. Journal of American Academy of Dermatology, Vol.54, No.1, pp.61-63.

Menter, A., Feldman, S.R., Weinstein, G.D., Papp, K., Evans, R., Guzzo, C., Li, S., Dooley, L.T., Arnold, C. \& Gottlieb, A.B. (2007). A randomized comparison of continuous vs. intermittent infliximab maintenance regimens over 1 year in the treatment of moderate-to-severe plaque psoriasis. Journal of American Academy of Dermatology, Vol.56, No.1, pp.31.e1-15.

Menter, A., Tyring, S.K., Gordon, K., Kimball, A.B., Leonardi, C.L., Langley, R.G., Strober, B.E., Kaul, M., Gu, Y., Okun, M. \& Papp, K. (2008). Adalimumab therapy for moderate to severe psoriasis: A randomized, controlled phase III trial. Journal of American Academy of Dermatology, Vol.58, No.1, pp.106-115.

Menter, A., Augustin, M., Signorovitch, J., Yu, A.P., Wu, E.Q., Gupta, S.R., Bao, Y. \& Mulani, P. (2010). The effect of adalimumab on reducing depression symptoms in patients with moderate to severe psoriasis: a randomized clinical trial. Journal of American Academy of Dermatology, Vol.62, No.5, pp.812-818.

Montané, E., Sallés, M., Barriocanal, A., Riera, E., Costa, J. \& Tena, X. (2007). Antitumor necrosis factor-induced neutropenia: a case report with double positive rechallenges. Clinical Rheumatology, Vol.26, No.9, pp.1527-1529.

Nestle, F.O., Kaplan, D.H. \& Barker, J. (2009). Psoriasis. New England Journal of Medicine, Vol.361, No.5, pp.496-509.

Nograles, K.E., Brasington, R.D. \& Bowcock, A.M. (2009). New insights into the pathogenesis and genetics of psoriatic arthritis. Nature Clinical Practice Rheumatology, Vol.5, No.2, pp.83-91.

Novartis. (July, 2010). Research and development: clinical pipeline. In: www.novartis.com, 16.05.2011, available from: http://www.novartis.com/downloads/investors/presentationsevents/pipeline-update/2010/2010-11-17-making-science_happen.pdf.

Ortonne, J.P., Reich, K., Sterry, W. \& Terpstra, I. (2008a). Safety and efficacy (PASI 90 and global evaluation) of subcutaneous certolizumab pegol in patients with moderate to severe chronic plaque psoriasis: results from a doubleblind, placebo-controlled trial. Journal of the American Academy of Dermatology, Vol.58, Ab.4, San Antonio, 66th Annual Meeting of the American Academy of Dermatology (AAD), February 1-5.

Ortonne, J.P., Reich, K. \& Keininger, D.L. (2008b). Certolizumab pegol improved healthrelated quality of life in patients with psoriasis: data from a phase II study. Journal of the American Academy of Dermatology, Vol.58, Ab.121, San Antonio, 66th Annual Meeting of the American Academy of Dermatology (AAD), February 1-5.

Paller, A.S., Siegfried, E.C., Langley, R.G., Gottlieb, A.B., Pariser, D., Landells, I., Hebert, A.A., Eichenfield, L.F., Patel, V., Creamer, K. \& Jahreis, A. (2008). Etanercept treatment for children and adolescents with plaque psoriasis. New England Journal of Medicine, Vol.358, No.3, pp.241-251.

Paller, A.S., Siegfried, E.C., Eichenfield, L.F., Pariser, D., Langley, R.G., Creamer, K. \& Kricorian, G. (2010). Long-term etanercept in pediatric patients with plaque psoriasis. Journal of the American Academy of Dermatology, Vol.63, No.5, pp.762-768.

Papoutsaki, M., Chimenti, M.S., Costanzo, A., Talamonti, M., Zangrilli, A., Giunta, A., Bianchi, L. \& Chimenti, S. (2007). Adalimumab for severe psoriasis and psoriatic 
arthritis: an open-label study in 30 patients previously treated with other biologics. Journal of the American Academy of Dermatology, Vol.57, No.2, pp.269-275.

Papp, K., Tyring, S., Lahfa, M., Prinz, J., Griffiths, CE., Nakanishi, A.M., Zitnik, R., van de Kerkhof, P.C. \& Melvin, L. (2005). A global phase III randomized controlled trial of etanercept in psoriasis: safety, efficacy, and effect of dose reduction. The British Journal of Dermatology, Vol.152, No.6, pp.1304-1312.

Papp, K.A., Caro, I., Leung, H.M., Garovoy, M. \& Mease, P.J. (2007). Efalizumab for the treatment of psoriatic arthritis. Journal of Cutaneous Medicine and Surgery, Vol.11, No.2, pp.57-66.

Papp, K.A., Langley, R.G., Lebwohl, M., Krueger, G.G., Szapary, P., Yeilding, N., Guzzo, C., Hsu, M.C., Wang, Y., Li, S., Dooley, L.T. \& Reich, K. (2008). Efficacy and safety of ustekinumab, a human interleukin-12/23 monoclonal antibody, in patients with psoriasis: 52-week results from a randomised, double-blind, placebo-controlled trial (PHOENIX 2). The Lancet, Vol.371, No.9625, pp.1675-1684.

Papp, K., Crowley, J., Ortonne, J.P., Leu, J., Okun, M., Gupta, S.R., Gu, Y. \& Langley, R.G. (2011). Adalimumab for moderate to severe chronic plaque psoriasis: efficacy and safety of retreatment and disease recurrence following withdrawal from therapy. The British Journal of Dermatology, Vol.164, No.2, pp.434-441.

Pfizer. (January, 2010). Pfizer pipeline. In: www.pfizer.com, 16.05.2011, available from: http://www.pfizer.com/files/research/pipeline/2010_0127/pipeline_2010_0127.pdf.

Piccolo, D., Di Cesare, A., Fargnoli, M.C., Paolini, M., Vecchiotti, S. \& Peris, K. (2008). Effective control of psoriasis by etanercept in a patient with HCV-related diseases. European Journal of Dermatology, Vol.18, No.4, pp.459-482.

Raho, G., Vena, G.A., Bizzoca, A., Cassano, N., Garofalo, E., Congedo, M. \& Gennarini, G. (2010). Influence of infliximab on keratinocyte apoptosis in psoriasis patients. Immunopharmacology and Immunotoxicology, Vol.33, No.1, pp.227-231.

Ramos-Casals, M., Brito-Zerón, P., Soto, M.J., Cuadrado, M.J. \& Khamashta, M.A. (2008). Autoimmune diseases induced by TNF-targeted therapies. Best Practice $\mathcal{E}$ Research Clinical Rheumatology, Vol.22, No.5, pp.847-861.

Reich, K., Nestle, F.O., Papp, K., Ortonne, J.P., Evans, R., Guzzo, C., Li, S., Dooley, L.T. \& Griffiths, C.E. (2005). Infliximab induction and maintenance therapy for moderateto-severe psoriasis: a phase III, multicentre, double-blind trial. The Lancet, Vol.366, No.9494, pp.1367-1374.

Reich, K., Nestle, F.O., Papp, K., Ortonne, J.P., Wu, Y., Bala, M., Evans, R., Guzzo, C., Li, S., Dooley, L.T. \& Griffiths, C.E. (2006). Improvement in quality of life with infliximab induction and maintenance therapy in patients with moderate-to-severe psoriasis: a randomized controlled trial. The British Journal of Dermatology, Vol.154, No.6, pp.1161-1168.

Reich, K., Ortonne, J.P., Kerkmann, U., Wang, Y., Saurat, J.H., Papp, K., Langley, R. \& Griffiths, C.E. (2010). Skin and nail responses after 1 year of infliximab therapy in patients with moderate-to-severe psoriasis: a retrospective analysis of the EXPRESS Trial. Dermatology, Vol.221, No.2, pp.172-178.

Revicki, D., Willian, M.K., Saurat, J.H., Papp, K.A., Ortonne, J.P., Sexton, C. \& Camez, A. (2008). Impact of adalimumab treatment on health-related quality of life and other patient-reported outcomes: results from a 16-week randomized controlled trial in 
patients with moderate to severe plaque psoriasis. The British Journal of Dermatology, Vol.158, No.3, pp.549-557.

Roberts, L. \& McColl, G.J. (2004). Tumour necrosis factor inhibitors: risks and benefits in patients with rheumatoid arthritis. Internal Medicine Journal, Vol.34, No.12, pp.687693.

Roberts, J.L., Ortonne, J.P., Tan, J.K., Jaracz, E. \& Frankel, E. (2010). The safety profile and sustained remission associated with response to multiple courses of intramuscular alefacept for treatment of chronic plaque psoriasis. Journal of American Academy of Dermatology, Vol.62, No.6, pp.968-978.

Russell, C.B., Kerkhof, K., Bigler, J., Timour, M., Welcher, A.A., Novitskaya, I., Khatcherian, A., Krueger, J., Rand, H., Martin, D.A. \& Zeichner, J.A. (2010). Blockade of IL-17R with AMG 827 leads to rapid reversal of gene expression. Journal of Investigative Dermatology, Vol.130, No.S1, S46.

Saougou, I., Markatseli, T.E., Papagoras, C., Voulgari, P.V., Alamanos, Y. \& Drosos, A.A. (2011). Sustained Clinical Response in Psoriatic Arthritis Patients Treated with Anti-TNF Agents: A 5-year Open-Label Observational Cohort Study. Seminars in Arthritis and Rheumatism, Vol.40, No.5, pp.398-406.

Saurat, J.H., Stingl, G., Dubertret, L., Papp, K., Langley, R.G., Ortonne, J.P., Unnebrink, K., Kaul, M. \& Camez, A. (2008). Efficacy and safety results from the randomized controlled comparative study of adalimumab vs. methotrexate vs. placebo in patients with psoriasis (CHAMPION). The British Journal of Dermatology, Vol.158, No.3, pp.558-566.

Scallon, B.J., Moore, M.A., Trinh, H., Knight, D.M. \& Ghrayeb, J. (1995). Chimeric anti-TNFalpha monoclonal antibody cA2 binds recombinant transmembrane TNF-alpha and activates immune effector functions. Cytokine, Vol.7, No.3, pp.251-259.

Schottelius, A.J., Moldawer, L.L., Dinarello, C.A., Asadullah, K., Sterry, W. \& Edwards, C.K. 3rd. (2004). Biology of tumor necrosis factor-alpha- implications for psoriasis. Experimental Dermatology, Vol.13, No.4, pp.193-222.

Shikiar, R., Heffernan, M., Langley, R.G., Willian, M.K., Okun, M.M. \& Revicki, D.A. (2007). Adalimumab treatment is associated with improvement in health-related quality of life in psoriasis: patient-reported outcomes from a phase II randomized controlled trial. Journal of Dermatological Treatment, Vol.18, No.1, pp.25-31.

Sterry, W., Ortonne, J.P., Kirkham, B., Brocq, O., Robertson, D., Pedersen, R.D., Estojak, J., Molta, C.T. \& Freundlich, B. (2010). Comparison of two etanercept regimens for treatment of psoriasis and psoriatic arthritis: PRESTA randomised double blind multicentre trial. The British Medical Journal, Feb 2; 340:c147. doi: 10.1136/bmj.c147.

Swedish Medical Center (September, 2009). Rituxan With or Without Methotrexate in Psoriatic Arthritis. In: www.clinicaltrials.gov, 16.05.2011, available from: http://clinicaltrials.gov/ct2/show/NCT00509678.

Thaçi, D., Ortonne, J.P., Chimenti, S., Ghislain, P.D., Arenberger, P., Kragballe, K., Saurat, J.H., Khemis, A., Sprøgel, P., Esslinger, H.U., Unnebrink, K. \& Kupper, H. (2010). A phase IIIb, multicentre, randomized, double-blind, vehicle-controlled study of the efficacy and safety of adalimumab with and without calcipotriol/betamethasone topical treatment in patients with moderate to severe psoriasis: the BELIEVE study. The British Journal of Dermatology, Vol.163, No.2, pp.402-411. 
Toichi, E., Torres, G., McCormick, T.S., Chang, T., Mascelli, M.A., Kauffman, C.L., Aria, N., Gottlieb, A.B., Everitt, D.E., Frederick, B., Pendley, C.E. \& Cooper, K.D. (2006). An anti-IL-12p40 antibody down-regulates type 1 cytokines, chemokines, and IL12/IL-23 in psoriasis. The Journal of Immunology, Vol.177, No.7, pp.4917-4926.

Trinchieri, G. (2003). Interleukin-12 and the regulation of innate resistance and adaptive immunity. Nature Reviews. Immunology, Vol.3, No.2, pp.133-146.

Tyring, S., Gordon, K.B., Poulin, Y., Langley, R.G., Gottlieb, A.B., Dunn, M. \& Jahreis, A. (2007). Long-term safety and efficacy of $50 \mathrm{mg}$ of etanercept twice weekly in patients with psoriasis. Archives of Dermatology, Vol.143, No.6, pp.719-726.

UCB, Inc. (December, 2010). Cimzia package insert. In: www.cimzia.com, 28.05.2011, available

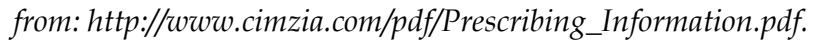

Vaishnaw, A.K. \& TenHoor, C.N. (2002). Pharmacokinetics, biologic activity, and tolerability of alefacept by intravenous and intramuscular administration. Journal of Pharmacokinetics and Pharmacodynamics, Vol.29, No.5-6, pp.415-426.

van de Kerkhof, P.C., Segaert, S., Lahfa, M., Luger, T.A., Karolyi, Z., Kaszuba, A., Leigheb, G., Camacho, F.M., Forsea, D., Zang, C., Boussuge, M.P., Paolozzi, L. \& Wajdula, J. (2008). Once weekly administration of etanercept $50 \mathrm{mg}$ is efficacious and well tolerated in patients with moderate-to-severe plaque psoriasis: a randomized controlled trial with open-label extension. The British Journal of Dermatology, Vol.159, No.5, pp.1177-1185.

van Eden, W. (2008). XToll, a recombinant chaperonin 10 as an anti-inflammatory immunomodulator. Current Opinion in Investigational Drugs, Vol. 9, No.5, pp.523533.

van, L., Modi, S.V., Yang, D.J. \& Hsu, S. (2008). Sustained efficacy and safety of adalimumab in psoriasis treatment: a retrospective study of 49 patients with and without a history of TNF-alpha antagonist treatment. Archives of Dermatology, Vol.144, No.6, pp.804-806.

Vena, G.A. \& Cassano, N. (2007). Anti-tumor necrosis factor therapies for psoriasis. Expert Review of Dermatology, Vol.2, pp.335-349.

Weger, W. (2010). Current status and new developments in the treatment of psoriasis and psoriatic arthritis with biological agents. The British Journal of Pharmacology, Vol.160, No.4, pp.810-20.

Williams, B., Vanags, D., Hall, S., McCormack, C., Foley, P., Weiss, J., Johnson, B., Latz, E. \& Feeney, D. (2008). Efficacy and safety of chaperonin 10 in patients with moderate to severe plaque psoriasis: evidence of utility beyond a single indication. Archives of Dermatology, Vol. 144, No.5, pp.683-685.

Yawalkar, N., Tscharner, G.G., Hunger, R.E. \& Hassan, A.S. (2009). Increased expression of IL-12p70 and IL-23 by multiple dendritic cell and macrophage subsets in plaque psoriasis. Journal of Dermatological Science, Vol.54, No.2, pp.99-105.

Zaba, L.C., Cardinale, I., Gilleaudeau, P., Sullivan-Whalen, M., Suárez-Fariñas, M., FuentesDuculan, J., Novitskaya, I., Khatcherian, A., Bluth, M.J., Lowes, M.A. \& Krueger, J.G. (2007). Amelioration of epidermal hyperplasia by TNF inhibition is associated with reduced Th17 responses. The Journal of Experimental Medicine, Vol.204, No.13, pp.3183-3194. 
Zeinn, N.N. \& Etanercept Study Group. (2005). Etanercept as an adjuvant to interferon and ribavirin in treatment-naive patients with chronic hepatitis $C$ virus infection: a phase 2 randomized, double-blind, placebo-controlled study. Journal of Hepatology, Vol.42, No.3, pp.315-322. 


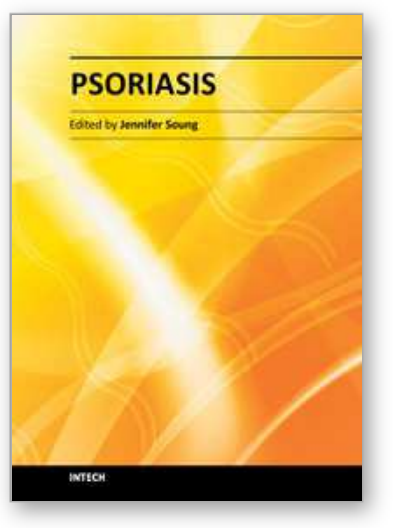

\author{
Psoriasis \\ Edited by Dr. Jennifer Soung
}

ISBN 978-953-307-878-6

Hard cover, 372 pages

Publisher InTech

Published online 15, February, 2012

Published in print edition February, 2012

We hope you enjoy and find the information provided in this book useful in your research or practice. We urge that you continue to keep abreast of the new developments in psoriasis and share your knowledge so that we may advance treatment and cures of psoriasis.

\title{
How to reference
}

In order to correctly reference this scholarly work, feel free to copy and paste the following:

Daria Capece, Valeria lansante, Mariafausta Fischietti, Daniela Verzella, Maria Concetta Fargnoli, Ketty Peris, Roberto Giacomelli, Francesca Zazzeroni and Edoardo Alesse (2012). Biotech on the Rise: The Treatment of Psoriasis with Biological Drugs, Psoriasis, Dr. Jennifer Soung (Ed.), ISBN: 978-953-307-878-6, InTech, Available from: http://www.intechopen.com/books/psoriasis/biotech-on-the-rise-the-treatment-of-psoriasis-withbiological-drugs-

\section{INTECH}

open science | open minds

\author{
InTech Europe \\ University Campus STeP Ri \\ Slavka Krautzeka 83/A \\ 51000 Rijeka, Croatia \\ Phone: +385 (51) 770447 \\ Fax: +385 (51) 686166 \\ www.intechopen.com
}

\author{
InTech China \\ Unit 405, Office Block, Hotel Equatorial Shanghai \\ No.65, Yan An Road (West), Shanghai, 200040, China \\ 中国上海市延安西路65号上海国际贵都大饭店办公楼405单元 \\ Phone: +86-21-62489820 \\ Fax: $+86-21-62489821$
}


(C) 2012 The Author(s). Licensee IntechOpen. This is an open access article distributed under the terms of the Creative Commons Attribution 3.0 License, which permits unrestricted use, distribution, and reproduction in any medium, provided the original work is properly cited. 